\section{Property management in China: opportunities and problems}

\author{
$\mathrm{L}$ ing $\mathrm{H}$ in $\mathrm{Li}$
}

\section{The author}

Ling Hin Li is an Assistant Professor in the Department of Real Estate \& Construction, The University of Hong Kong, Hong Kong.

\section{Abstract}

The development of the real estate market in China has been well-documented, but one of the most interesting, yet chaotic issues in this market has not been fully covered. It is the problems and opportunities arising from the needs for the management of existing properties. Supply of prime office buildings in the major cities in China has been unprecedented owing to the strong demand from local and overseas companies. To preserve the investment value of the building, there is a great need for good management. How ever, those who have worked in a socialist country will understand that service industry is always the weakest point of the economy. It is, nevertheless, exactly for this reason that there is a great opportunity for established property management companies to expand their service not only in property management but also in the training of the new generation of local property managers in this potential market.

\section{Introduction}

Property management is emerging as a managerial science today (K yle and Baird, 1995). Q uite different from the past, property management professionals now perform more than the role of rent collector or plumber. A good property manager pays a lot more attention to the needs of the tenants than in the past because good property management practice is about serving the users rather than the physical building. At the same time, the property manager should be very sensitive to the changes in the economic environment so that contingency plans can be made for the owners in terms of cash-flow planning. This is not always an easy job in a mature real estate market with proper market regulation and well-developed market practice. This is even worse in a newly developed market with no experience in property management, such as in the emerging socialist economies.

E ver since the opening up of the property market in $\mathrm{C}$ hina, a number of international real estate consultancy firms in $\mathrm{H}$ ong $\mathrm{K}$ ong with property management divisions have been very busy sending staff to various cities in $C$ hina to manage prime office buildings and high class residential developments. M ost of the real estate development projects in $\mathrm{C}$ hina which are marketed in $\mathrm{H}$ ong $\mathrm{K}$ ong emphasize a " $\mathrm{H}$ ong $\mathrm{K}$ ong style of property management" as one of their selling points.

In this emerging property market, prime properties have been the focus of most of the developers' attention, as demand from overseas users has been very strong, especially from those international companies which are keen on opening offices in China (Walker and $\mathrm{Li}, 1994)$. In addition, as the local economy in the major cities in China starts to improve, living standards will also improve. This will lead to a growing demand for proper management service of the premises. N evertheless, property management is a very intangible commodity and the effect is always felt in the long term. To the rapidly changing market in China, development of good property management practice may prove to be problematic on one hand and profitable on the other. In the following paragraphs, this paper examines the potential market for good management companies and then discusses the possible problems they have to bear in mind.
Property Management

Volume $15 \cdot$ Number $1 \cdot 1997 \cdot$ pp. 6-11

o MCB University Press · ISSN 0263-7472
Received February 1996

Revised September 1996 


\section{The opportunities}

Table I shows a very brief account of statistics available for the latest development in the office markets in four of the major regional sub-markets in $\mathrm{C}$ hina. $\mathrm{T}$ hese markets represent the most active real estate markets in $\mathrm{C}$ hina. Beijing is the capital city of $\mathrm{C}$ hina and, given its political status, a lot of firms will try to make a presence there. Shanghai is the future financial capital of $\mathrm{C}$ hina with substantial support from the central G overnment; while in southern $C$ hina, $G$ uangzhou is the most economically prosperous city, and Shenzhen is a typical example of the special economic zone. There follows an analysis of the office markets in Beijing and Shanghai for the examination of the long-term potential market for good property management.

\section{Annual supply of office space in Beijing and Shanghai}

Table II illustrates the historical supply of office space in each of these two markets.

When the data in Table II are plotted (see Figure 1), it is evident that the annual percentage increase in the two cities behaved in different ways. F rom 1990 to 1994 (except 1991/92), there has been a steadily upwardsloping curve in Shanghai's office supply, while a more fluctuating performance in Beijing is evident for the same time period. 1993/94 saw a rapid increase in office supply in Beijing and a steady growth in Shanghai. $T$ he issue becomes the justification of this growing supply of office space for this "opportunity" for the management professional to be

Table I Brief account of the four regional office markets in China

\begin{tabular}{|c|c|c|c|}
\hline Project ${ }^{a}$ & $\begin{array}{l}\text { Completion date } \\
\text { (estimated) }\end{array}$ & $\begin{array}{c}\text { GFA } \\
(10,000 \mathrm{sq} . \mathrm{m})\end{array}$ & $\begin{array}{l}\text { Sale price } \\
\text { (US\$/sq.m) }\end{array}$ \\
\hline \multicolumn{4}{|l|}{ Beijing } \\
\hline Sunshine Square & End of 1995 & 15 & 2,200 \\
\hline Duke Square & 1997 & 1.5 & 1,800 \\
\hline East Ring Plaza & 1995 & 21 & 2,500 \\
\hline Celebrity Plaza & 1996 & 2 & 2,200 \\
\hline Wangfujin Century Square & End of 1995 & 5 & 4,000 \\
\hline Henderson Centre & End of 1996 & 28 & 3,800 \\
\hline Wantong New World Square & End of 1995 & 11 & 3,300 \\
\hline Investment Square & mid-1996 & 5.1 & 2,700 \\
\hline \multicolumn{4}{|l|}{ Shanghai } \\
\hline Sino Plaza & 1997 & 1.7 & na \\
\hline Shanghai Plaza & 1997 & 4.7 & na \\
\hline Huaneng Building & 1997 & 7.2 & na \\
\hline Bund Square & 1997 & 12.45 & 2,200 \\
\hline Concordia Square & 1997 & 8 & na \\
\hline Ganglu Huangpu Center & 1996 & 1.8 & 2,898 \\
\hline China Trade Council Building & 1996 & 5.8 & 2,700 \\
\hline \multicolumn{4}{|l|}{ Guangzhou } \\
\hline Variety Square & End of 1995 & na & 1,600 \\
\hline Huahai Building (new wing) & End of 1996 & na & 1,436 \\
\hline Zhongtian Square & 1996 & na & 2,900 \\
\hline Good World Square & 1996 & na & 2,760 \\
\hline Central City Square & 1996 & na & 2,677 \\
\hline Liwan Square & End of 1995 & na & 1,862 \\
\hline Liuhau Square & 1995 & na & 1,028 \\
\hline \multicolumn{4}{|l|}{ Shenzhen } \\
\hline Jinli Commercial Square & 1995 & na & 1,717 \\
\hline Xinxing Square & 1995 & na & 2,627 \\
\hline Louhu Square & 1995 & na & 2,416 \\
\hline Wenjin Square & 1995 & na & 1,400 \\
\hline \multicolumn{4}{|c|}{$\begin{array}{l}\text { Note: aAuthor's own translation may be different from developer's version of the English names of the } \\
\text { properties }\end{array}$} \\
\hline \multicolumn{4}{|l|}{ Source: Wang and Wan (1995) } \\
\hline
\end{tabular}


Table II Cumulative supply of office space in Shanghai and Beijing (sq.m)

\begin{tabular}{lcc}
\hline Year & Beijing & Shanghai \\
\hline $\mathbf{1 9 8 9}$ & $3,622,000$ & $6,334,500$ \\
$\mathbf{1 9 9 0}$ & $3,862,000$ & $6,364,900$ \\
$\mathbf{1 9 9 1}$ & $4,050,000$ & $6,553,000$ \\
$\mathbf{1 9 9 2}$ & $4,354,000$ & $6,670,000$ \\
$\mathbf{1 9 9 3}$ & $4,626,000$ & $6,946,400$ \\
$\mathbf{1 9 9 4}$ & $4,860,000$ & $7,171,400$
\end{tabular}

Source: Statistical Yearbook of Beijing (1994); Statistical Yearbook of Shanghai $(1992,1994)$

\section{Figure 1 Annual percentage increase of office stock in Shanghai and Beijing}

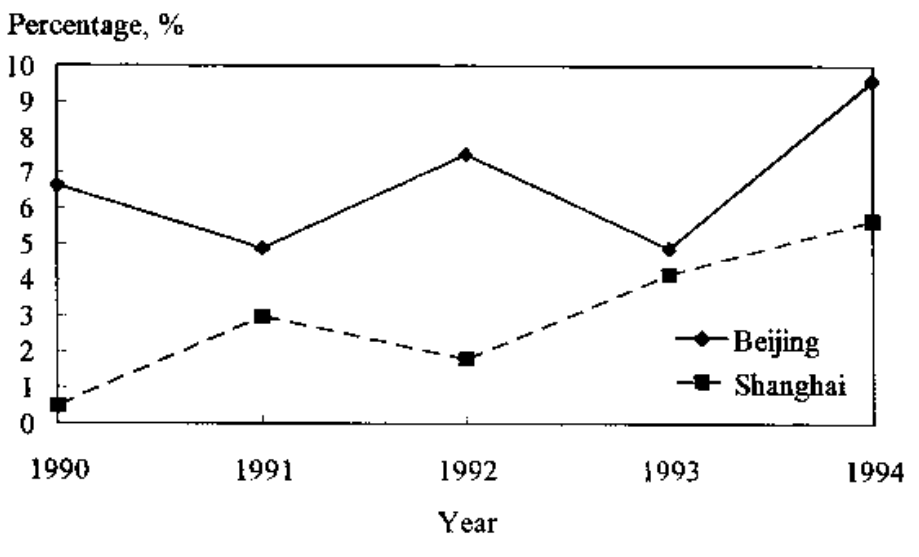

established. $\mathrm{H}$ ence, it is necessary to examine the demand side of the office market.

\section{Occupancy}

Table III and Figure 2 demonstrate that the occupancy patterns are approximately the same in the period of 1989 to 1992. T here was a drop in the occupancy rate in 1990 and 1991 and, after that, the occupancy rate increased again in a steep slope. In 1992 and 1993, there were high occupancy rates in both cities. For Shanghai, there was a great increase in 1993. In 1993 and 1994, both cities had occupancy rates which were above 90 per cent. In 1994, the percentages were so high that the office markets were approximately fully occupied. In other words, the supply could not meet the demand side.

\section{Revenue base of the office markets in Beijing and Shanghai}

O ne of the prerequisites for good property management is to have a good revenue base in the office market so that a high quality service and maintenance schedule can be maintained.
Table III Occupancy rates in Shanghai and Beijing

\begin{tabular}{lcc}
\hline Year & Beijing (\%) & Shanghai (\%) \\
\hline 1989 & $75^{\mathrm{a}}$ & $50^{\mathrm{b}}$ \\
1990 & $67^{\mathrm{c}}$ & $39^{\mathrm{b}}$ \\
1991 & $67^{\mathrm{c}}$ & $35^{\mathrm{b}}$ \\
1992 & $90^{\mathrm{c}}$ & $58^{\mathrm{b}}$ \\
1993 & $95^{\mathrm{c}}$ & $93^{\mathrm{b}}$ \\
1994 & $98^{\mathrm{a}}$ & $99^{\mathrm{d}}$ \\
Source & \\
b Shanghai Report (1994) & \\
CBeijing Report (1994) \\
d Shanghai Property Market(1995) \\
\hline
\end{tabular}

It is actually a self-preserving mechanism as high quality service can also guarantee a better bargaining position by the landlord to achieve a higher rent. On this basis, the office markets in $\mathrm{C}$ hina seem to provide a rather promising picture, as can be seen in $\mathrm{F}$ igure 3 .

$\mathrm{H}$ ence, it can be deduced from the simple analysis in Figure 3 that there is a developing office market with an increasing supply of prime office buildings built not only by local developers but also by developers from outside $C$ hina. Such an increasing supply is strongly absorbed by a latent demand for good quality offices. T his seems to be a good opportunity for property management companies to develop their market share. This, however, is only true if the problems associated with this market can be solved.

\section{The problems}

There are basically two major obstacles in developing good management practice in C hina's property market. T he first is training and staffing. In any socialist economy, personal service has always been associated with capitalist evil so that it was never regarded as important. As long as the "goodwill" of a company providing services to customers does not form a vital part of the business value and bad and poor quality of service cannot be punished by the customers going elsewhere (N ove, 1992), "good" management will not be given enough credit in the real estate industry. T he current imbalance between the supply of good quality offices and the demand for them makes it possible for local managers to overlook the importance of the value given to human factors by the tenants when choosing their ideal office space. $\mathrm{H}$ ence, an open market is still not competitive enough to allow 
Figure 2 Occupancy rates in Shanghai and Beijing

Occupancy Rate, \%

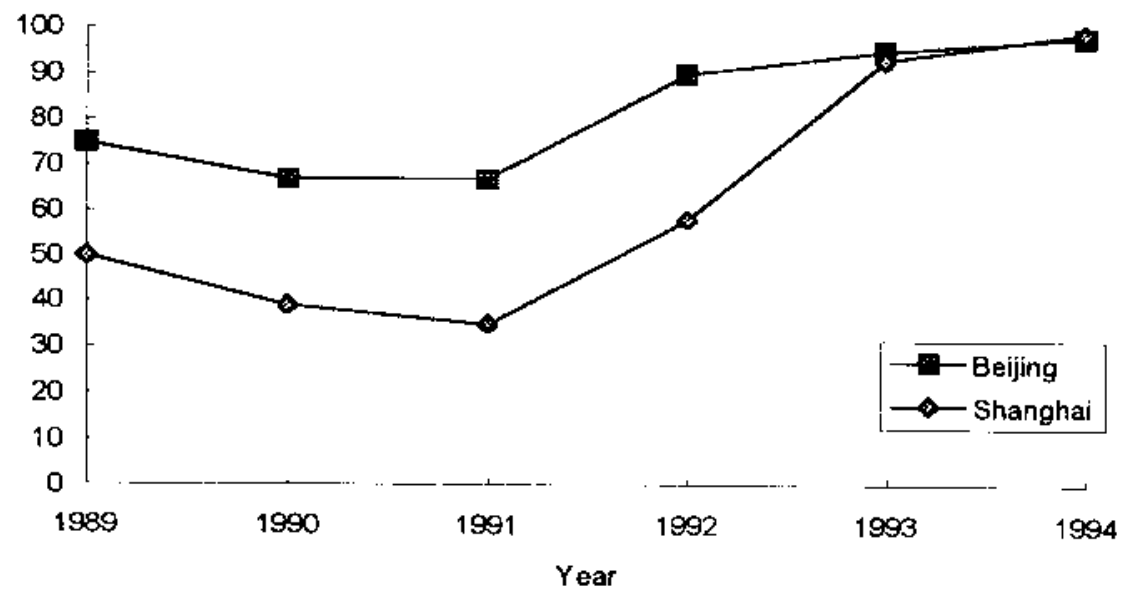

Figure 3 Office rent US\$/sq.m per month

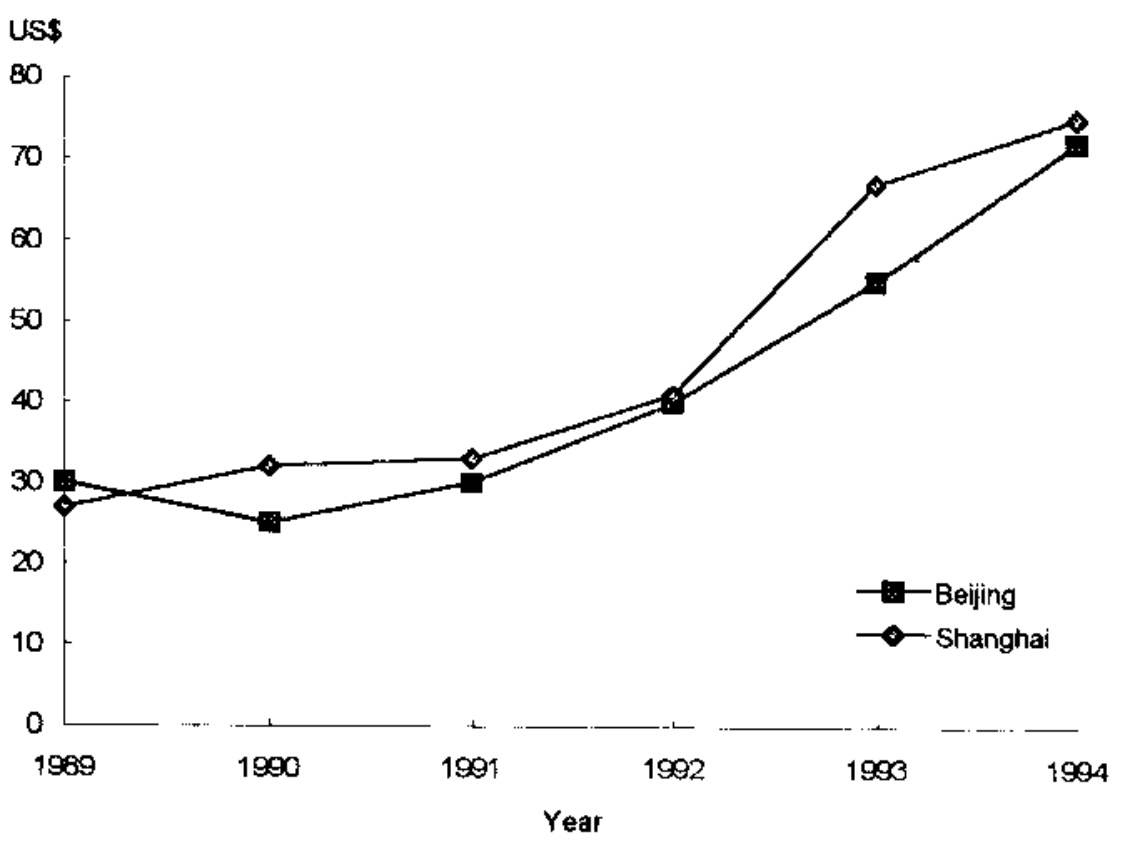

the freedom of choice to influence the price mechanism.

As a result, it is very difficult to convey this intangible concept to the operating staff. For instance, although local $\mathrm{C}$ hinese people understand the importance of security to the firms occupying the buildings, the local security guards still insist on having lunch all together at the same time. H ence, there will be no security guards during lunch hours. To them, it is a welfare benefit, and flexible lunch hours are not acceptable. Sometimes, it is the local custom that creates problems in the staffing issue. For instance, in Beijing, anybody who gets married after the age of 23 is regarded as making a late marriage. The local custom is that people who are above the age of 23 and who get married during their term of employment are entitled to a ten-day late marriage leave. This adds to the problem of the under supply of qualified management staff.

According to the $C$ hina Statistical Yearbook (1995), about 50 per cent of the staff employed in the real estate industry were management staff, the rest belong to development and agency. If it is assumed that this is the national standard, then there will be 21,000 property management staff in Beijing and 21,500 in Shanghai. According to Table II, the 21,000 workforce in Beijing will have to take care of about 5 million sq.m of office 
space and the 21,500 workforce in Shanghai will have to manage about 7 million sq.m of space, bearing in mind that the supply of office space in the coming years is ever increasing in these two places. In addition, there is no way to find out if the figures for the workforce represent qualified management staff.

T he Institute of R eal Estate $M$ anagement (1991) suggests that an orientation programme be reinforced for new staff with an employee manual so that they will understand the general rules of employment as well as the company's policies affecting internal and external relationships. This should be supplemented by a compensation scheme to retain valuable staff. In the social ist economy, such a policy will depend very much on the extent to which the level of wages can be allowed to be adjusted freely by the employers. In addition, an even more important determinant is the long-standing wage discrimination among local $C$ hinese staff and staff brought in from outside $C$ hina. A number of employers are very reluctant to increase wages and bonuses to local staff because one of the reasons that foreign companies employ local staff is the cheap wage rate. H owever, capable local staff should be compensated accordingly as they are more valuable to the company than expatriates, since local staff are more committed and sensitive to the local environment. If a channel is open for local staff to compete for the same bonus and salary system as expatriates, the competitiveness will modify some of the inappropriate local habits.

T he second obstacle is the contractual relationship between the management company and new tenants. U nder current management practice, a management contract is signed between the management company and the original owners of the building. Since there is no $D$ eed of $M$ utual $C$ ovenant (or $D M C$, which is a normal practice in $\mathrm{H}$ ong $K$ ong) by which all subsequent purchasers of the building will be bound by the clauses in the covenant, new purchasers or users of the office units will have no responsibility for a predecessor's or tenant's liabilities. Without a proper understanding and acceptance of the contractual relationship and duties between the management company and property users, it will be very difficult to safeguard the property rights of the owners of the building. As a result, the management staff will have to be very vigilant whenever they find new occupiers moving in or they may have to liaise with all tenants about the possibility of the change of landlord or users in their units. Once new users or owners of any unit are identified, they will have to be persuaded to sign a new management contract with the management company so that a binding contractual relationship can be formed. In this way, there is actually a burden on the part of the management company in terms of both the paperwork and the associated costs. G iven the relatively weak concept of contract law in C hina, it seems that the individual arrangement with each landlord/tenant/user is very important. At this stage, there is basically nothing the foreign property management companies can do apart from adopt this personal approach.

\section{The solution}

Given the potential office market examined above, it is obvious that demand for good quality property management in C hina is inevitable in the long run from landlords in order to maintain a steady income for their buildings. This is especially important in some of the major cities such as Shanghai's where an increasing supply of prime offices targeting at international and profitable local companies is evident in the coming years. In entering into this potential market, for the time being, property management consultants, in particular international ones, should try to establish a joint venture scheme with a local partner so that management efficiency can be increased through the "informal channel" by the $\mathrm{C}$ hinese partner. $T$ his is especially important when more and more local firms are occupying prime offices for their trading activities. With the relatively weak concept of contractual relationships and property rights, more interpersonal skills must be employed when dealing with local tenants in the short run.

Stapleton (1994) advocates the positive management approach which is very much needed at present in China, although it is always much easier said than done. In this transitional period of the real estate market in $C$ hina, it is very important for the management professionals to strengthen their position in order to establish their creditability in the market. In the short to medium term, acceptance of the local custom seems to be 
the solution to the staffing problem. Positive benefits must be shown to the users of the building for them to understand that a covenant-type of contractual relationship must be established for the most efficient use of the property.

In the long run, comprehensive in-house training of local staff with an appropriate bonus scheme is the only solution. This will be more economical than bringing in management staff from overseas. I n training local staff, an operation manual is essential for local staff to follow with proper guidance. For instance, the following is the operation manual for management staff in a prime office building in Beijing:

- All assets of the building will be audited every six months.

- Disposal of assets, or any materials must be certified by the relevant section supervisor and verified by the property manager. For plant and machinery, it must be verified by the technical manager.

- Order lists of materials for management will be made every month after considering the inventory and cash-flow position.

- Inventory and stores will be audited every month.

- Issue of keys must be recorded.

- Staff meetings should be held everyday after 5.00 p.m. to make sure management understands the operation problems or any particular issues the operation staff want to draw to the management's attention.

- Complaints from tenants must be properly recorded and responded to.

This list may contradict the normal manage ment practice in a socialist state, hence care must be taken in implementing, the manual and proper guidance and a communication channel must be provided by the management.

\section{Conclusion}

It is obvious that there are many problems for the implementation of good property management in this emerging property market. It is also quite difficult for local people to understand the intangible value of good property management practice. Given the current under-supplied office market, it may not emerge as a potential advantage to the landlords, especially the local landlords. $\mathrm{H}$ owever, given this growing market, it will only be a matter of time before local landlords understand the value to be added to their buildings by good management practice and local tenants realize the efficiency they can enjoy during their occupation. This is especially the case when the supply of good quality buildings is increasing in various cities, and competition among cities and buildings will soon be very keen. By that time, quality of service will eventually affect the investment value of the buildings which will force the landlords to re-vitalize good management practice. In this interim period, a system must be established by more delicate means of interpersonal communications rather than a rigid working manual. It is always important to remember that the basic management tool in good property management practice is human resources and the target of service is people rather than the physical building. In a traditional socialist economy such as C hina, successful application of interpersonal communication accounts for a much higher rate of achievement.

\section{References and further reading}

Bachner, J.P. (1991), The Guide to Practical Property M anagement, McGraw-Hill, New York, NY.

Beijing Property Market (1995), Research Department of Brooke Hillier Parker, Hong Kong.

Beijing Report (1994), C.Y. Leung \& Co. Ltd, Hong Kong.

China Statistical Yearbook (1995) China Statistical Publishing House,, Beijing.

Institute of Real Estate M anagement (1991), Principles of Real Estate Management, IREM, Chicago, IL.

Kyle, R.C. and Baird, F.M .(1995), Property Management, Real Estate Education Company, Chicago, IL.

Loo K.F. (1991), A Guide to Effective Property Management in Hong Kong, HK University Press, Hong Kong.

Nove, A. (1992), "Soviet reforms and western neo-classical economics", in Kovacs, J.M. and Tardos, M. (Eds), Reform and Transformation in Eastern Europe, Routledge, London.

Philpott, S. and Hicks, G. (1994), "M anaging business tenants", Estates Gazette, London.

Shanghai Property Market (1995), Research Department of Brooke Hillier Parker, Hong Kong.

Shanghai Report (1994), C.Y. Leung \& Co. Ltd, Hong Kong.

Stapleton, T. (1994), "Estate management practice", Estates Gazette, London.

Statistical Yearbook of Shanghai (1992, 1993 and 1994), China Statistical Publishing House, Beijing.

Statistical Yearbook of Beijing (1994), China Statistical Publishing House, Beijing.

The Investors' Handbook for Hong Kong and China, (1995), Pitman Publishing, Hong Kong.

Walker, A. and Li, L.H. (1994), "Land use rights reform and the real estate market in China", Journal of Real Estate Literature, Vol. 2, pp. 199-211.

Wang, X. and Wan, G. (1995), Estate Price of China, China Product Price Press, Beijing. 